\title{
Of Belonging and Becoming: Black Atlantic (Inter-)Cultural Memory in the Early Autobiographies of Peter Abrahams and Es'kia Mphahlele*
}

\section{Kgomotso Masemola}

Peter Abrahams was a major New African intellectual of the New African Movement. The New African Movement was a particular historical eventuation consisting of intellectuals, writers, musicians, political leaders and religious figures who - between the years 1904 and 1960 - constructed a singular form of modernity in South Africa known as "New African modernity." One of the strongest outside forces influencing the construction of New African modernity was New Negro modernity in the United States. A singular achievement of Peter Abrahams was to have imported to South Africa the literary modernism of the Harlem Renaissance. This was done through his novels, short stories and poems. When he went into exile in 1939 at the age of twenty, he navigated black cosmopolitanism through the philosophy of Pan-Africanism, which was the quintessential ideology of black modernism across the first half of the twentieth century.

Artistic expression, expanded beyond recognition from the grudging gifts offered by the masters as a token substitute for freedom from bondage, therefore becomes the means towards both individual selffashioning and communal liberation. Poesis and poetics begin to exist in novel forms autobiographical writing, special and uniquely creative ways of manipulating spoken language, and, above all, music. All three have overflowed from the containers that the modern nation state provides for them. (Paul Gilroy)

When David Attwell remarks that in Es'kia Mphahlele 'we have the most sustained record of the encounter between a black South African writer and the cultures of the diaspora' (Attwell 2001:1), he does so less to traduce the import and impact of Peter Abrahams and others who wrote from exile, than to reveal, by varying degrees, one of the most salient features of Mphahlele's

* To cite this article: Kgomotso Masemola (2004): Of belonging and becoming:

Black atlantic (Inter-)cultural memory in the early autobiographies of Peter Abrahams and Es'kia Mphahlele, Current Writing: Text and Reception in Southern Africa, 16:2, 47-70 
self-writing: the differential scope of cultural translation borne of the Black Atlantic 'encounters' that inform autobiographical writing qua a simulacral cultural memory. Whilst Roger Bromley notes that the intercultural and transnational formations described by Paul Gilroy in The Black Atlantic (1993) constitute a basis pursuant to which emphasis is placed on "cultures of encounter and the possibility of belonging simultaneously, mentally, psychologically and experientially, to a diversity of cultures" (2000:7), I will claim that encounters also held the prospect of becoming, of articulating a discursive migrancy, of reconfiguring the subject of cultural discourse, and of an active reconsititution of - rather than merely belonging to, thriving by and borrowing from - the intercultural archive of transnational Black Atlantic figures of memory. Furthermore, I will draw correspondences between specific modes of cultural memory as described by Jan Assman (1995) and specific orders of repetition as delineated by Gilles Deleuze (1998), showing how in Mphahlele and Abrahams Black Atlantic figures of memory are repeated as simulacra of the Black Atlantic assemblage, with each textual combination of mode and order representing the extent of belonging and becoming as well as the ontological tension between the two intensities.

In order to fully grasp the extent of the aforesaid Black Atlantic encounters it is important to note that, over a twenty-year period, Mphahlele was writing in a manner that attests to his engagement with intellectual movements in the black world, from West and East Africa where he taught in universities and co-founded cultural centres, to France, the Caribbean and even the United States where he studied and also taught in universities, working alongside figures such as Houston Baker, Jr. and Sonia Sanchez, amongst others. In between he managed sojourns in London and, importantly, in Paris where he met and contested ground with the proponents of the Negritude movement. All these encounters, intercultural and radicalised as they come to be in cultural memory, were to be felt in his subsequent work, notably but not exclusively, in his autobiography. Abraham's canvass is just as broad, since he lived abroad from 1939 and, after settling down with a white woman in 1941, he moved to France to 'work out a lasting basis for their union' (Ogungbesan 1979:5), after which stay he returned to London for what was to be the resurrection and bitter reburial of his Communist Party links. Unlike Mphahlele, though, his visit to Kenya took the form of a meeting with Jomo Kenyatta, brief and en route to Britain, from where he would later decide to strike root in Jamaica. In his latest autobiography, The 
Black Experience in the Twentieth Century (2000), we discover that his political activism involved encounters with George Padmore and Langston Hughes during his New York visit, as well as experience of Black Power and Rastafarian movements in Jamaica, the high point of which recollections is Mandela's visit to Jamaica. The encounters that Mphahlele and Abrahams experienced in the diaspora are very important for an understanding of how the cultural memory that informs autobiographical writing as a postcolonial practice constitutes a translational discursive migrancy in what Bhaba calls 'a shifting cultural terrain rooted in specific histories of cultural displacement' whereby

Culture is translational because such spatial histories of displacement - now accompanied by the territorial ambitions of 'global' media technologies - make the question of how culture signifies, or what is signified by culture, a rather complex issue. (1994:172)

My argument is that in Tell Freedom (1954) and Down Second Avenue (1959), the earlier autobiographies of Abrahams and Mphahlele, the memoric record of cultural displacement encapsulates the potential to reconfigure the subject of cultural discourse, where writing would reflect the manner in which the voyage out of racist South Africa was accompanied by immersions into, and constant re-evaluations of, new modes of representation. They had to reconfigure the cultural scripts of a Black Atlantic modernity in order to forge their space in the battle for a selfing regime of representation. After all, cultural memory is exactly about that sort of translation:

The concept of cultural memory comprises that body of reusable texts, images, and rituals specific to each society in each epoch, whose cultivation serves to convey and stabilize that society's self-image. Upon such collective knowledge, for the most part (but not exclusively) of the past each group bases its awareness, unity and particularity. (Assman 1995:130)

Critical moments of articulation of positions are often refracted in the writing moment as the one voice tries to fit itself into a Black Atlantic assemblage whose unity effectively depends on a continuing struggle for representation. This struggle often means that the options of operationalizing identity-making (becoming) or identification (belonging) in narrative correspond with the two modes of cultural memory: "in the mode of potentiality of the archive whose accumulated texts, images, and rules of conduct act as a total horizon, and second in the mode of actuality, whereby each contemporary context puts the objectivized meaning into its own perspective" (Assmann 1995:130). 
Kgomotso Masemola

However I argue further: the indices of the use or concretization of black Atlantic figures of memory and the extent of their simulacral repetition show that Abrahams's narrative sometimes operates in the limited mode of the potentiality while Mphahlele's cultural memory contemporises according to contingencies of his actual situation. Given historical contingencies that attend specific histories of struggle, often according to geopolitical divisions, positioned accounts of the encounters of the diaspora cannot be rooted - or even routed - in a stable Black Atlantic narrative. The diaspora has no settled culture. So that as the process of affirmative 'selfing' ensues, or even as disavowals confirm new positions, the record of these encounters emerges as cultural translations of fixed points of cultural memory which, in effect, are:

fateful events of the past, whose memory is maintained through cultural formation (texts, rites, monuments) and institutional communication (recitation, practice, observance). We call these 'figures of memory' ... in the flow of everyday communication such festivals, rites, epics, poems, images, etc, form 'islands of time', islands of a completely different temporality suspended from time. In cultural memory, such islands of time expand into memory spaces of 'retrospective contemplativeness' [retrospective Bessonneheit]. (Assmann 1995:129)

Seen in this light, autobiography is a process by which Abrahams and Mphahlele defined themselves through writing against the oppressive society of South African society by appropriating texts and monuments from the African diaspora while, in the same breath, writing for an imagined community to which they belonged and aspired through the observance of, say, established figures of the Afro-American world. For example, the memory of the fateful events, often racial, of Abrahams's life are maintained through the recitation of W E B Du Bois's The Souls of Black Folk, and he finds the phrase 'The Negro is not free' pointing to many fateful events in his life (Abrahams 1954:193). It becomes more than a painful refrain but a powerful figure of memory in which "a collective experience crystallizes, whose meaning, when touched upon, may suddenly become accessible again across millennia" (Assmann 1995:129).

Autobiography yokes the past to the present and posits a differential cultural identity of blackness. Stuart Hall points out that such writing in the diaspora involves the production of a cultural identity, a 'oneness' based on the foregrounding of the past of a shared culture through the significant 
difference which results in "what we really are" and "what we have become" in the course of historical intervention - a matter of "becoming as well as being" (Hall 1990:226). It is noteworthy that Abrahams was quite impressed with the Afro-American section of the library of the Bantu Men's Social Centre in Doornfontein, a fact which is also borne out by Mphahlele in Down Second Avenue as he reminisces about the extent of the influence that Marcus Garvey had on the young Abrahams and the fervour with which he embraced him when they were much younger in their college days:

I remember him talking about Marcus Garvey, taking it for granted that we must know about him. And dreamily he said what a wonderful thing it would be if all the Negroes in the world came back to Africa.

Abrahams wrote verse in his exercise books and gave them to us to read. I admired them ... I remember now how morose the verse was: straining to justify and glorify the dark complexion with the I'm-black and proud-of-it theme ... I regarded him as a conqueror. I had a vague feeling that his opinion of Marcus Garvey typified him as someone who was always yearning for far-away places. (Mphahlele 1959:128-129)

The diasporic circuit, that very nomadic object and matrix of "yearning for far-away places", defines the ontological basis of blackness beyond mere aesthetic glorification or its simple identification with the Afro-American world. In Tell Freedom Abrahams better expresses this ambivalence of blackness as belonging and becoming in his memory of Mad Nondi, a boy who worked with him at 'the smithy'. Besides being a very funny fellow, even though he was big in size, he often "laughed and cried for no apparent reason" (1954:121). Nondi embodies the ambivalence to South African urban working life, and Abrahams connects himself to him, desiring to have his intense expressiveness when he is overwhelmed by a strong sense of space and grandeur on the top of a hill near Krugersdorp: "I suddenly longed for Nondi to be on this hill with me" (Abrahams 1954:124). The intensity, resulting in an outburst, represents yearning for being more than one, for being Coloured and Black African, for producing an identity of shared culture through a "significance of difference" (Hall 1990:226). The irrepressible outburst that Abrahams lets out is an utterance that performatively expresses an assemblage usually prohibited by the settled culture of apartheid segregation policy.

Deleuze puts it in this way:

... in an assemblage there are, as it were, two faces, or at least two heads. There are states of things, states of bodies (bodies interpenetrate, mix together, transmit affects to one another); but also utterances, 
Kgomotso Masemola

regimes of utterances: signs are organized in a new way, new formulations appear, a new style for new gestures (the emblems which individualize the knight, the formulas of oaths, the system of 'declarations', even of love, etc). (Deleuze and Parnet 1987:70-71)

Within this formulation falls the affects transmitted between Joseph the Zulu boy and the then younger narrator, Lee, in Elsberg, as they spend the long afternoons together, exploring the river, swimming, learning to fight with sticks, catching frogs and locusts, hearing voices of the wind in the willows, and hearing their two childish voices in laughter with these (1954: 44-5). In this mixing of disparate things as "states of things" are produced utterances which designate Joseph's mother as a mother to both boys: never once does Joseph call her "my mother" nor does Lee call her "your mother". The new utterance organises her designation into the epithets of "the mother" or "the little mother" throughout (1954:45-47). With and through Joseph, and later through Abrahams's mother's revelation of his Abyssinian roots, "brother Lee of the Coloureds" (1954:46) becomes "Lee of the Abyshinins!" (1954:61) now proudly serving his kings in far-way Abyssinia (1954:61). This reference to Ethiopia interestingly calls to mind Marcus Garvey's envisaged return to Ethiopia while, in Lee's context, it refers to a city of the mind connecting him to Joseph through the emblems of "black kings before the white man came" (1954:45).

It is not surprising then to find that an Interlude in Mphahlele's autobiography invokes the recitation of the story of Moses, the fortunate Hebrew child born of Levi and taken into the care of Pharaoh's daughter. It becomes a figure of memory for him, not so much because it was imposed by the school teacher, but more that in the re-imagining of cultural memory, the young Mphahlele is lying flat on the bank of a river, wondering how wonderful it would have been to "be so free, so lovable" (1959:47). In that moment one cannot but help thinking about the painful refrain in Du Bois's tome and Abrahams's life: "the Negro is not free!" In choosing to look at his life by contradistinction, by looking at his life as different from Moses' he evokes a recurring image of deliverance from slavery as framed in the Negro spiritual. Through this figure of memory in which Egypt and its river gives a home, Mphahlele, unlike Abrahams, goes beyond recitation but transforms the emblems and figures of memory by finding not only what is common but what is different. He proceeds to show the importance of difference by insisting that the explanation of the circumstance of Moses cannot put pieces of his life together. He has to look at his own, again by 
contradistinction: "They are a jumble” (1954:75). That river in Abrahams's autobiography is simply re-imagined as a river of hope. By contrast, in Mphahlele it brings closer the reality of his time. His is Leshoana River:

The cruel river everyone has to cross. Merciless waters beating about the banks, rolling big boulders and trees on its broad back as if in some crude Satanic jest. Dark grey waters frowning at you as you stand in a little rising, not daring to come near, not daring to gaze too long ... I jump into sitting position. No, no fear here. And yet Leshoana is like that. (Mphahlele 1959:75)

Mphahlele's ambivalence towards the river of his childhood and of Egypt amends its concretion as a figure of memory. The river can be as much disquieting as it is charming. It inspires a "terrified, breathless and foolish laughter", a response that makes him observe, "How playful violent things can be" (1959:75). The utter seriousness of the river's danger contrasts sharply with the idyllic predisposition of Abrahams's. When the river comes alive, frowning, it ceases not being a referential object and gains a life of its own, animated by its threat to wash into its torrent those who are in its way. It is very real on its course, galvanising into action innocents who might seek to romanticise it "in some crude Satanic jest". Yet it needs to be appreciated as it is, not glorified to match some romantic ideal. Perhaps the suggestion is that not everything is beautiful in Africa's nature. His appropriation of the river departs from its association with the celebration of blackness in the fashion of the Harlem Renaissance, something that I find overdone in Abrahams's use of the river as a monumental figure of memory. The reason for this might be his stress on identification with the ideals of the Harlem Renaissance. I find no better illustration than in 'The Negro Speaks of Rivers', a poem by Langston Hughes:

I've known rivers:

I've know rivers ancient as the world and older than the flow of Human blood in human veins.

My soul has grown deep like the rivers.

I bathed in the Euphrates when dawns were young

I built my hut near the Congo and it lulled me to sleep.

I looked upon the Nile and raised the pyramids above it.

I heard the singing of the Mississippi when Abe Lincoln went down to New Orleans, and I've seen its muddy bosom turn all golden in the sunset

I've known rivers:

Ancient, dusky rivers. 
Kgomotso Masemola

My soul has grown deep like the rivers.

(Hughes and Bontemps 1949:105-106)

This poem is not unknown to Mphahlele because he writes his autobiography having completed research on the portrayal of the non-white character for his MA degree thesis in 1956. His survey included Langston Hughes, Countee Cullen, Richard Wright and Claude McKay, amongst others (1959:195). It seems to me a deliberate stance that his appropriation of the river is transformed to assert the particularity of the South African problem in the unity of the black assemblage. To insist upon such awareness requires a deviation from the model of the Black Atlantic as a stable unity. Only the mark of difference within that 'oneness' makes the cultural memory in Mphahlele more radical than that of Abrahams, whose reluctance to cultivate the figures of memory does not allow him space to be sufficiently reflexive. Assman describes cultural memory as reflexive in three ways:

(a) it is practice-reflexive in that it interprets common practice in terms through proverbs, maxims, "ethnotheories", and so on

(b) It is self-reflexive in that it draws on itself to explain, distinguish, reinterpret, criticize, censure, control, surpass, and receive hypoleptically

(c) It is reflective of its own image insofar as it reflects the self-image through a preoccupation with its own social system (Assmann 1995:130).

In places Abrahams does partake of the ethnotheories of blackness through figures of memory such as the institutional communication of the recitation of passages from Du Bois's work on the colour-line problem of the twentieth century, reflectively contemporising it through the image of the Negro who is not free (1954:193). Where he does less so is at the point of introducing Paul Robeson through song. The emphasis is on the "glorious" black man's voice "that had given us a common identity" (1954:192). He proceeds to give us excerpts of the song's lyrics, deliberately beginning with the lines "There's an old man called the Mississippi /That's the old man that I'd like to be ...", which are purposely interrupted so that he can once again home in on "That old man river / ...He keeps on rolling - along" (1954:191). The river as it appears in Tell Freedom is not part of recast objectivised culture in cultural memory, not interpreted but merely recited. The intention to place himself at the heart of the New Negro's colour-line struggles elides the peculiarity of the South African case in the Black Atlantic. The river, "the old man Mississippi", is what Abrahams would like to be. 
In the fashion of Edward Said's formulation of repetition, Henry Louis Gates, Jr disapproves of unproblematic repetitions of images, insisting instead that facts should not be merely vindicated but given by the amendment of their direction (Gates 1989:56). Similarly, the tracts of the 'New Negro' are not to be vindicated but given by the amendment of their direction. The case of Mphahlele's Leshoana River is exemplary. Contrast this with Abrahams' re-memory of the river in Elsberg:

In the long summer afternoons, after my day's work, I went down the river ... Sometimes I watched the springhaas - the wild rabbit of the veld - go leaping across the land, almost faster than the eye could follow. And sometimes I lay on my back, on the green grass; on the bank of the river, and looked up at the distant sky, watching thin fleecy white clouds form and re-form and trying to associate the shapes with the people and things I knew. I loved being alone by the river. It became my special world.

Each day I explored a little more of the river, going further up or down stream extending the frontiers of my world. One day, going further downstream than I had been before, I came upon a boy. (1954:42-43)

Perhaps it is Abraham's fondness for and ownership of the Everyman edition of John Keats that allows him to lend romantic colour to his description of the river scene, looking at the clouds that are amenable to a poet's imagination. In this instance he seems to successfully cultivate the Keatsian imagination, until a point where one notices the obvious similarities of style between the passage and Countee Cullen's 'Heritage' poem, especially from its second stanza:

So I lie, who all day long Want no sound except the song Sung by wild barbaric birds Goading massive jungle herds, Jaggernauts of flesh that pass Tramping tall defiant grass Where young forest lovers lie, Plighting troth beneath the sky. So I lie...

(Hughes and Bontemps 1949:122)

As the young Abrahams ensconces himself in a world of pristine nature, wallowing in the green grass observing the sky, the neo-Romantic ideals of Cullen become all the more palpable. What Abrahams does here is simply to crystallize the collective experience of black people, finding something 
redeeming in nature, something that is facile to the Romantic imagination, something to make Nature in art a vindication of the humanity of blacks. Where Robeson finds the Mississippi the river he wants to be, Countee Cullen expresses the need to remember its primordial African scenery from the third line of the third stanza of his "Heritage" poem: "Unremembered are her bats/... her cats/ crouching in the river reeds ..." (Hughes and Bontemps 1949:123), and Abrahams imitates - as if to complete a romantic genealogy - when he declares, "I loved being alone by the river. It became my special world" (1954:42). Suffice to say that whenever Abrahams imitates the Black Atlantic figures of memory, it is merely - and consciously - to identify with the Romantic black world, to belong to the Black Atlantic assemblage rather than become within it.

As evidenced above, the river is special to Abrahams, not because of its objectivisation of culture but for its place in memory. It is the memoric concretion of identity, its Black cultural figures of which Cullen is one, that makes it special. Imitation rather than the self-reflexive impulse of cultural memory becomes the hallmark of the neo-romantic strain in Abraham's remembrance of nature. In a different context, Gates cautions against such imitation as it repeats

all that can be imitated, everything exterior, appearance, gesture, intonation, and dress. To do so would be to repeat the mistake of a Romantic poet such as Countee Cullen, for whom form was a container into which he could pour a precious and black content. (Gates 1989:56)

However, it is understandable that Cullen and later Abrahams sought to imitate the form and content of a past. The racial and oppressive context of their writing meant that objects outside of their temporality had to give cohesion to their work's countercultural function in relation to racism and its institutions. Perhaps it is the imitation of the imitation - repeating Cullen who repeats Keats - that attenuates the efficacy of cultural memory in the encounter with nature in Tell Freedom. This kind of identification, based on the common experience of the racial problem of the twentieth century, does not have the capacity to reinterpret that experience, much less account for the dynamics of the peculiarity of class and perhaps gender in the black world. Cultural memory, by virtue of its limitless islands of time, provides the opportunity for a retrospective contemplativeness that radicalises memory.

But Abrahams's repetition of the Keatsian image is not reflective of its own image insofar as it reflects the self-image through a preoccupation with 
its own social system (Assman 1995:130). It might seem as if his autobiography cannot successfully negotiate the tension between becoming and belonging. The problem, though, is that the repetition of the repetition does not continue with doubling and splitting in order to both radicalise and emblematise its figures of memory. Through this kind of repetition, Tell Freedom's autobiographical 'I' remains in a multiplicity that only deterritorializes the struggle into the black Atlantic but cannot seem to reterritorialise it.

Deleuze extrapolates Nietzsche's notion of the Eternal Return in his delineation of three types of repetition in representational time, differentiated by selectiveness and intensity:

The highest test is to understand the eternal return as a selective thought, and repetition in the eternal return as selective being. Time must be understood and lived as out of joint, and seen as a straight line which mercilessly eliminates those who embark upon it, who come upon the scene but repeat only once and for all. The selection occurs between two repetitions: those who repeat negatively and those who repeat identically will be eliminated. They repeat only once. The eternal return is only for the third time ... The eternal return is only for the third repetition, only in the third repetition. (Deleuze 1994:299)

There is no doubt that Abrahams's was selective thought, electing to mobilize only those figureheads that best represented commonalities. At the same time one cannot help but notice that, in some parts of Tell Freedom, instantiated by the Keatsian imagination, or rather the repetition of Cullen's neo-romanticism, he could not repeat blackness further as a selective being. Instead he "repeats identically" (Deleuze 1994:299). As I said before, the problematic of representing the autobiographical 'I' is best understood as a negotiation of the space between belonging and becoming, between being part of the black Atlantic and unfolding in such a manner as to articulate difference, between identifying with a formation of a Black struggle and earning a place by an innovative expanding of boundaries as opposed to propounding its beliefs. The 'position' I have described, one of acknowledging shifts, is more representative of Frantz Fanon who writes that "In the world through which I travel, I endlessly create myself ... And it is by going beyond the historical, instrumental hypothesis that I will initiate my cycle of freedom" (Fanon 1986:229-230), and I believe it better explains why Stuart Hall, one of the many postcolonial critics he influenced, describes diaspora identities as "constantly producing and reproducing 
Kgomotso Masemola

themselves anew, through transformation and difference" (Hall 1994:402). That the production and reproduction of these identities is constant, transformational and based on difference further highlights what ought to prevail in Abrahams's autobiography. What obtains instead is the second order repetition, despite the fact that the book was written in exile. In 'telling freedom' did Abrahams not produce himself anew, though?

Two things are apparent. First, somewhere in Tell Freedom's narrative the absence of the black man's freedom calls for the first order of repetition, that is, negative repetition; for this would affirm the humanity denied by racist South Africa. Second, the New Negro served not only as an image, but a horizon that heralded what seemed to Abrahams to be an enlightened liberation discourse by blacks outside South Africa, something 'authentic' and worth emulating. This explains the identical repetition in which he was bound. It is not a weakness as such, but a symptom of a lack of reflexiveness in cultural memory, a resolute stance which seeks rigorously to pursue the idea of an alternative society by powerfully acknowledging not only the context but the ubiquity of Blackness as both problematic and beautiful in the Black Atlantic. A continuous splitting or doubling would further problematise his discourse on race, as did his attempts to continue the political work he had begun with worker unions in Cape Town and Durban. His problems with Marxists in London, where he was to shy away from the Party after he got into trouble for refusing to submit two books for clearance by the Party was symptomatic. He "believed the sort of control they wanted to exercise was too much like what obtained in South Africa, and he felt that, like the colour bar from which he had fled, Marxism was inhibiting his desire to see the world in the round" (Ogungbesang 1979:4). This awakening brings to view the need on his part for a double enunciation (as a nonEuropean and as a Marxist) of even those figures of memory that have a fixed horizon in his memory. As part of the islands of time they can only censure and transform in the multiplicity of the black assemblage on the basis of a double enunciation that addresses itself to the black and white binary. He finds that he faces an historical imperative described by Gilroy, that is, to

stand between (at least) two great cultural assemblages, both of which have mutated through the course of the modern world that formed them and assumed new configurations. At present, they remain locked symbiotically in an antagonistic relationship marked out by the symbolism of colours which adds to the conspicuous cultural power of their central Manichean dynamic - black and white. (Gilroy 1993:1-2) 
On the whole, though, what initially seems like a lack of deftness regarding the reflexive transformations of figures of memory is remedied by Abrahams' acknowledgement by of a struggle within a multiplicity at other places in Tell Freedom. The life of Abrahams is not a simple record of events captured in a binary of racial diachotomies but an attempt to "tell freedom" as the title of his book suggests. His telling of freedom charts a striking trajectory of becoming within a diasporic circuit whose assemblage of blackness highlights the abstract machines of difference at the level of local signification. There is effective deterritorialisation from the ideal world of the West or the city and a simultaneous reterriotrialisation of the writer's habitus when Abrahams and his friend Jonathan dismiss the notion - and fiction - of a better life of equality in the city during one long walk in the environs of Grace Dieu, his alma mater outside Pietersburg. Here, in a passage that I will quote at length, two voices in conversation are conflated into one as a scenario of Jonathan's failed conversion to a new person is painted:

A boy is satisfied with his village, and the life of his village, because he knows no other. That is his life, that is the life of the ancestors before him. And, for him, it is a good life. He herds his cattle and observes the rules and laws of the tribe. He is content.

And then the white man comes into his contentment. The white man shows him new things and new ways. And he is no longer content with the old ways. The white man says the key to this world is to become a Christian and to have knowledge and education. The boy looks at the things of this new world. He finds them good ...

And so he becomes a Christian and goes to school. Knowledge brings new desires, new beliefs: the god of love in place of pagan gods of war of old; the new view of the stranger, the foreigner, as a brother to be welcomed rather than an enemy to be destroyed or feared; long dreams of a new life; new ways of thinking and responding open to him. The vision of the humble Christ, the father of all men, of all races and colours, supplants the little gods of old.

And so the boy turns his back on the old ways of the ancestors ... he goes to the city to see and get to know ... because it is the symbol of his new world. (Abrahams 1954:235-236)

Perhaps the above scenario is ominous for Abrahams himself when he is about to leave South Africa. The allure of the "pilgrimage" to England and the Harlem he was waxing lyrical about earlier on at the Bantu Men's Social Centre (1954:200) held for him the potential of finding "new ways and new 
things" in the West. In any case Rathebe, one of the longstanding and progressive members at the Social Club, had told him that England had no colour bar and that "the great Paul Robeson lived there!" (1954:199). However, the incident with the Communist Party predates his autobiography by two decades, and it demystifies as well as disabuses the pilgrimage status of his pilgrimage in England. That he stubbornly dotes on the Manichean dynamic of race after so many years of living in the metropolis is surely indicative of the manner in which his cosmopolitan identity was shaped. England's heaths and lanes seemed not to inspire the beauty he found in her poets. As he writes Tell Freedom from England's backyard, the colours of his art are still only two: black and white.

It is in this sense that I want to argue that Rathebe's England had stirred something in Abrahams, just as the city boys' narrative had led Jonathan to Christianity and the white man's new ways. His is a desperate need to leave the country, so he could find a place where he could supplant the little gods of racist South Africa. Like his friend Jonathan he would "get to know" because the metropolis, if not England, "is the symbol of his new world" (Abrahams 1954:236). Equality as envisioned in the figure of "Christ the father of all colours and races" in the city was disabused by a single event shamefully recalled in a moment of reciprocal candour between Abrahams and his friend:

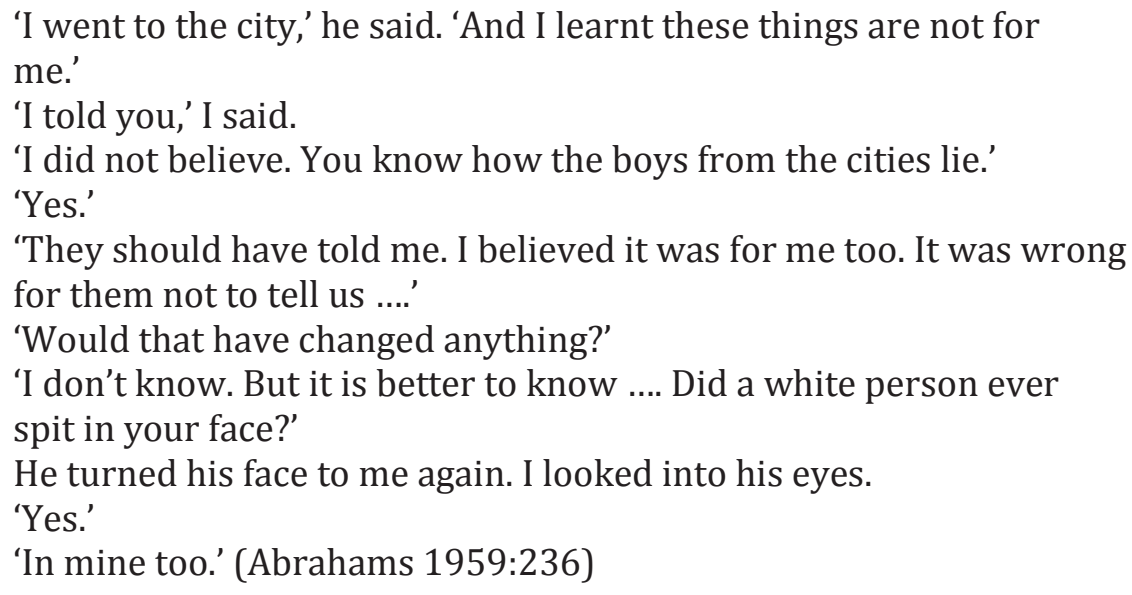

Writing with the benefit of hindsight, Abrahams might as well be suggesting that Rathebe, the well-travelled man who sold him and others who yearned for freedom the world of Robeson, should have told him. Even though England did not in itself present a discourse of Christian egalitarianism in 
any explicit way, the next best thing was the Communist Party in London whose proscriptions were, perhaps, a kind of condescension from which he would want to further escape to Jamaica. It was not exactly a spit in the face but an encounter that shifted the focus from the base-and-superstructure model to a race-and-superstructure one.

In Mphahlele's case that racial binary is present but deliberately problematised. He deliberately describes the rural village of Maupaneng outside Pietersburg as divided by a river, on either side of which lived heathens and Christians, the descriptive terms pejoratively used to demean each other. And he points to his Christian grandmother as a person who had very clean habits, to explain the popularity of the phrase "Dirty as a heathen" (Mphahlele 1959:20). But Mphahlele's narrative takes on an ambivalent tenor, showing how his incredulity towards the alleged witchcraft and evil of the heathens is fostered by their kindness when he went across to look for lost goats (1959:14). He then proceeds to re-tell a story which resolves the problems linked to the failed ethos of Christianity in the city beyond the racial spectre raised by Abrahams. He remembers Thema - a young man like Jonathan in Abraham's Tell Freedom - saying that despite Reverend Foster's claim that Christ died on the cross for us all, men were not brothers in the city, "Black man cooks the white man's food but eats what is left over. Don't listen to any one bluff you and say black and white are brothers" (1959:16-17). Upon his return, Thema, like Jonathan, is a changed man. What is important though is that Mphahlele explains not only loss of pride and dignity but his love and sanity. This he frames in a tragic love story between Thema and a heathen girl from Molepo's village. Her brothers found out, disapproved and beat him with sticks. Unfortunately, it was a rainy day and as he and the girl tried to run, the Leshoana River was overflowing. They barely managed to reach the other side of the river, thanks to the extraordinary strength of the girl, when a tree stump hooked her ankle wire. Thema had leapt on to the bank. The girl screamed for help but all Thema could do was was shout her name, and so she was carried away:

We found him lying on his stomach near the slope and brought him home. He told me all about it afterwards. Some say he's still alive, in a village far away, but I do know that he is a little off his head. That is the story of Thema and the pagan girl. (Mphahlele 1959:18)

Loss is treated differently here; for the life of a girl so brave is unnecessarily lost because of the divide between the Christians and the heathens. The 
Leshoana River accrues importance as a symbol of that division. Through the loss of the girl's life and Thema's sanity underscored by this river, we come closer to understanding its function as a figure of memory: to implode binarisms. Even more importantly, the story of Thema and the pagan girl is not Mphahlele's own memory. It is a memory that arises from a repetition of another storyteller's communication of collective memory around the storyteller's fire. Mphahlele contemporises the past in his cultural memory by going beyond negative repetition or identical repetition. Because of this, the question of the city's inequities and racism is given greater depth.

Mphahlele creates for the city's malaise a repetition through a quasiparallel text of discrimination by appropriating a reusable cultural text

drawn from the monument of communal-fire stories. However, by repeating in his autobiography as re-memory, he expresses this memory not only as part of communal fire's collective memory, or Old Segone the story-teller's re-memory, but the excess of these two, that is, the third repetition of the eternal return:

Repetition in the eternal return appears ... as the peculiar power of difference, and the displacement and disguise of that which repeats only reproduce the divergence and the decentring of the different in a single movement of diaphora or transport. The eternal return affirms difference, it affirms dissemblance and disparateness, chance, multiplicity and becoming. (Deleuze 1994:300)

Yet what is even more striking in Tell Freedom is its reflexive memory at the point where Abrahams remembers the return of Nandi to the smithy, two weeks after a racial incident where his boss assaulted him with a soldering iron, damaging his left eye. After an exchange of greetings that surprisingly shows no sign of bitterness on Nondi's part, Lee asks him if he is coming back the following day. His answer in the negative includes a statement of future directions:

He pointed at the setting sun.

'There! I'm going to see what it's like where the sun sets.'

'What for?'

'Don't be dumber than a dog, big eyes. I want to.'

'Where will you sleep? What'll you eat?'

'Where dogs eat: what dogs eat.'

'And your people?'

'I am my people.'

'But your mother and father.' 
The Early Autobiographies of Peter Abrahams and Es'kia Mphahlele

'I am my people .... Don't be worried, big eyes, I'll be all right.' (Abrahams, 1954:133)

The far-away places that Mphahlele sensed in Abrahams's impression of Marcus Garvey find resonance in Nondi's movement as he briskly walks "in the direction of the setting sun ... Perhaps he would turn ... But he did not turn" (1954:134), underscoring what Deleuze calls "an event which stretches out or contracts, a becoming in the infinitive" (Deleuze amd Parnet 1987:71). In this becoming, anticipated, as a space "where dogs eat" stretches itself further into suggesting that Nondi will live in that infinite becoming when he will "eat what dogs eat". This confirms animal-becoming, a state of limitless potential: between being man and being a dog arises an assemblage in which the dog and man dimension are irreducible to one another. This type of multiplicity defies the pejorative and demeaning history of Nondi who, being a man, was treated as dog first and labelled as such to consolidate the racist discourse of 'Othering'. For instance in the incident leading to his assault, his boss shouts at him, "Shut up and hurry up, you mad dog!" His use of dog is immediately subverted into an a-signifying regime in Nandi's immediate response, "A dog! Yes! No dog can fear as fears a man. The fears of dogs are fears of truth. I'll be a dog without your fears!" (Abrahams 1954:131). Instead of a repetition by negation, Abrahams's re-memory proffers an identical repetition by agreeing to being like the dog. But that was before the assault. As the above passage attests, he goes beyond agreeing by extending the lines of flight into a molecular aggregation with the dog and thus effects the third repetition. According to Deleuze, the "inbetweenness" of the line of flight between man and dog is an intensity that marks a becoming rather than a unity of its multiplicity:

There is indeed a historical question of the assemblage: particular heterogeneous elements caught in the function, the circumstances in which they are caught up, the set of relationships which at a particular moment unites man, animal, tools and environment. But man also never stops animal-becoming, tool-becoming, environment-becoming, according to another question within these assemblages. Man only becomes animal if the animal, for its part, becomes sound, colour or line. It is a bloc of becoming which is always asymmetrical. It is not that the two are exchanged ... (Deleuze and Parnet 1987:71)

This kind of becoming actually begins between Lee (the much younger Abrahams) and a little stray cat he brings home. He called the cat Moe because of the sound it makes (Abrahams, 1954:12). He complains that his 
parents would never permit him them to eat out of the same plate and instead were provided with "two identical little enamelled plates and ate side by side on the floor. And often, when others were not looking, we ate out of each other's plates. The food was much more tasty that way" (1954:13). A memory re-imagined from a toddler's perspective sets in motion blackbecoming between himself and Joseph in Elsberg, environment-becoming as he lay in the grass by the river bank, and culminates in the possibility of human-becoming as he is about to repeat the human-becoming voyage once taken by Frederick Douglass. In this infinite becoming he was repeating Nondi's animal-becoming when, like Nondi who sought to go "where the sun sets" (1954:133), he "walked briskly down to the docks. And all of my dreams followed me" (1954:311).

Kolawole Ogungbesan sees this moment as the last and final of many episodic moments within the larger theme of escape, noting that the book begins with a dream that ought to be realised outside South Africa (1979:86). This departure is a new beginning, an opportunity to "tell freedom", an opportunity arising out of the uneasy South African crisis on the eve of the Second World War, to realise dreams that were inspired by the likes of WEB Du Bois and Langston Hughes as he voyages to England by ship across the Atlantic. But more than that it is a process of becoming, fragmented enough to be misread as 'episodes' by Ogungbesan. It is a departure that marks an anticipated arrival at a polyvocal, multiple subjectivity earlier on:

My mind was divided. The call of America's limitless opportunities was strong. The call of Harlem, Negro colleges, and the 'New Negro' writers, was compelling. But Charles Lamb, Elia, John Keats, Shelley, and the glorious host they led, made a counter call. And my mind saw a peaceful land that offered peace to a poet. (1954:199)

When the moment arrives for Abrahams to board ship, his dreams "walking" with him, new possibilities of belonging and becoming arise: he will tell freedom like many before him who had to leave their people behind. In this he was moving from the molar multiplicity of black South Africa into the molecular multiplicity of the Black Atlantic. If the last dialogue between Abrahams and Nondi is anything to go by, the response from an obviously resolute Nondi when asked about the people he leaves behind, namely that 'I am my people' bespeaks a belonging that functions through its outside, as a multiplicity that

includes focuses of unification, centres of totalization, points of 
The Early Autobiographies of Peter Abrahams and Es'kia Mphahlele

subjectivation as factors that can prevent its growth and stop its lines. These factors are in the multiplicity to which they belong, and not the reverse. (Deleuze and Parnet 1987:71)

In being his people, Nondi realises that in unity lurks the possibility of a centre of totalisation that can prevent his going "where the sun sets". Growth involves moving from one's people in order to animate an alliance rather than union with them. Abrahams in like manner boards the ship to claim his manhood, to be "personally free" (1954:311), away from his people in order to 'tell freedom'. The ship he is to board holds out a significance that rivals expectations at the end of the destination. For he journeys through the seas on ship like the predecessors of the 'New Negro' he so admired, escaping the racial contradictions of South Africa and belonging to the Black Atlantic network. Paul Gilroy points out that this route, taken by ship - the white man's - is in itself "a powerful orientation to the ideologies of liberty and justice":

There is also the shining example of Frederic Douglass, whose autobiographies reveal that he learnt of freedom in the North from Irish sailors while working as a ship's caulker in Baltimore. He had less to say about the embarrassing fact that the vessels he readied for the ocean - Baltimore Clippers - were slavers, the fastest ships in the world and the only craft capable of outrunning the British blockade. Douglass, who played a neglected role in English anti-slavery activity, escaped from bondage disguised as a sailor and put this success down to 'talk sailor like an old salt.' [Douglass is one of] a few of the nineteenthcentury examples. The involvement of Marcus Garvey, George Padmore, Claude McKay, and Langston Hughes with ships and sailors lends additional support to Linebaugh's prescient suggestion that 'the ship remained perhaps the most important conduit of Pan-African communication before the appearance of the long-playing record'. (Gilroy 1993:13)

Abrahams in Tell Freedom becomes a crew member of a ship that is to be part of the Second World War effort that "divided the whites of the country into two camps" (1954:306), the pro-Hitler and pro-British segments, a war effort that in many ways resembles the North-South conflict of Frederic Douglass's time. Between the time Abrahams read the Afro-American section of the Bantu Men's Social Centre, where he not only heard Paul Robeson's voice on the long-playing record but also read Negro literature stating its anti-slavery record, and at the time of writing the record of his own life, Abrahams must have made a deliberate decision to connect 
himself to the Harlem greats through song and literature first and then through the ship. These three serve not only as the motif for selfing or becoming. They are important cultural figures of memory that connect memory as the contemporalized past and black people across the Atlantic into a set of historically defined reciprocal relationships.

I take it as significant that, at the point in Down Second Avenue where Mphahlele regards Abrahams as a conqueror, he is quick to add that reading, the very activity which led Abrahams to Garvey, also led him to Cervantes, Robert Lyndt, Alpha of the Plough, Steel, Goldsmith as well as Shakespeare, Dickens, 'Q' and R L Stevenson (1959:129). This is significant because years later, as Mphahlele states in the autobiography's Epilogue, he would declare his "impatience with Robert Browning's bloated certitudes about God" when his experience of life has been tempestuous (1959:219). Elleke Boehmer says the same of Abrahams who:

'desired to know himself' in terms of the standards set by Shakespeare and poetry... Again a double act was required: to remain vigilantly critical of the legacy of colonialism, but also, because it could not be entirely eliminated, to discover how to accommodate that legacy even while reinterpreting it. (Boehmer 1995:187)

As evidenced by the order of repetition in the act of reinterpretation, Mphahlele's was the more radical case of an on-going negotiation and restaging of values of modernity, progress and Enlightenment in the received forms of literary canons, education and Christianity, amongst others. This complicates the relationship between desire, education and identity. Education as an object of desire informed identity. But the humanistic African identity in Mphahlele, or indeed the affirmation of the Black experience in Abrahams, shows that they had to voyage out of that education in order to make sense of their place of freedom.

It is in the light of the translational function of cultural memory in Tell Freedom and Down Second Avenue that I wish to assert that Abrahams evinced a stronger awareness of Black unity instead of particularity than Mphahlele who demonstrates the two properties simultaneously. Abrahams's unity with his people is intelligently framed as a becoming which culminates in becoming-Negro à la Du Bois's double consciousness mode. From then on, becoming ceases and instead caves in on itself in a series of first and second order repetitions. For him the Black Atlantic becomes a molar multiplicity based on black unity. This inevitably results in a decision much larger than the double consciousness of being of the African diaspora and 
being South African. The Keatsian neo-romanticism in his depiction of the river is a case in point. Mphahlele, on the other hand, uses autobiography to re-imagine figures of memory in all its reflexive ways, stressing intensities of the eternal return. His depiction of the Leshoana river is enmeshed in a third order repetition of reusing the re-memory script of the fire-place storytellers. The same re-memory is in evidence when he cultivates a memory lesson about the biblical baby Moses. Transculturation in both Mphahlele and Abrahams relates to grounding the representation of both belonging and becoming in the memory of autobiography. For instance, as they recount their movement from the city to the countryside we have a sense of the negotiation of dislocation that both writers experience later as they 'voyage' into the diaspora in the West. Theirs is as much an informed writing practice as it is an informing genre. As Avtar Brah puts it, diasporic autobiography is "vulnerable to challenge from other representations as the vagaries" or self-representations of an individual, and "the credibility of this narrative of political moments and events is dependant far less upon the scribbling of an 'individual'; the individual narrator does not unfold but is produced in the process of narration" (1996:10). As opposed to the suggestive readings by Abioseh Nichol and James Olney (1973:44), which stress that childhood memories of African writers are essentially about "the enormous desire and striving for education", I want to stress that transculturation and cultivation and endless repetition were the implicit goal of what seemed to be fully proselytised mimic men.

A few years ago Catherine Woeber outlined the shift in the manner in which Mphahlele regarded missionary education, pointing to the fact that while Down Second Avenue shows how the missionary school environment of St Peter's allowed these writers to express themselves better, in the second instalment Mphahlele states that what they were learning at school had very little to do with daily torments and actual living conditions (Woeber 1995:66). For Woeber this is evidence that there are moments when memory plays tricks with an author, which actually constitutes a harsher version of Olney's position that ordering experience through autobiography requires the sifting of memories. However, a symptomatic reading throughout will show that there is neither sifting nor tricks, only the shifting 'self'. These shifts inform the signifying time of re-memory. They frame the problematic of representation as concomitant with the re-imagining of cultural memory, especially in the characteristic interpretive re-telling in the narrative of diasporic autobiography. My suspicion, however, is that 
Woeber seems to expect cultural memory to be the same as communicative memory, assuming that if autobiography has an audience then it must be actively involved in an exercise in filling gaps in the story, highlighting the fault-lines and debunking its myths and the odd lie here and there. As discussed above, certain radical forms of repetition are involved in cultural memory. It is not a simple iteration or imitation of what has been. That which is told has as its subject and object figures of memory from within and without the context of the autobiographical story. As Assman puts it, "cultural memory is characterized by its distance from the everyday" (1995:129).

This readily confirms the textual selves of Mphahlele and Abrahams as resident in a discursive space that simultaneously affords and regulates their conditions of possibility, predisposing them to the kinds of deterritorializations and reterritorialisations one finds in their cultural memory. Roger Bromley insists that culture is actually at the crossroads of multiple narrations and - I suspect by that very fact - rhizomatic (2000:99). He follows Deleuze and Guattari to propose a syncretism based on nomad space in order to endorse the production of counter-memories, counterhistories and counter-communities. I find this very interesting in that the indeterminancy of the diasporic movement is never ending, whereas cultural memory has its fixed points in narrative. Its texts are made to signify in distinct ways at distinct moments. The autobiographical writing moment is caught up in moments where new meanings - not meaninglessness - are endlessly produced by the deliberate and measured repetitions of figures of memory.

It remains to be said that while Paul Gilroy finds that incommensurable discourses of the black Atlantic in their varied themes "accentuate the inescapable fragmentation and differentiation of the black subject" (1993:35), Bhabha sees this as an opportunity in a process "peculiar to a specific, problematic kind of temporality ... peculiarly split and doubled in its effective implementation" (Attwell 1993:102). This fragmentation or doubling and splitting inevitably shows itself in the cultural memory of autobiography of Mphahlele and Abrahams, in varying degrees. I want to characterise this difference within the Deleuzean categories of repetition I discussed earlier on, arguing as I do so that the prevalence of negative and identical repetitions in Peter Abrahams and the proliferation of the third repetition, makes bold statements about the assemblages within which identity formation takes place in their narrative. By this I mean that the 
qualitative difference in their cultural memory should be understood in terms of cultural memory's two modes.

Squarely on the basis of the concretization of the river, and indeed of the orders of repetition, Tell Freedom tends to have more of the mode of potentiality, especially in his repetition of the New Negro figures of memory. Towards the end of the book, forms of becoming emerge in such a way as to reclaim a blackness based on multiplicity. Mphahlele's cultural memory, on the other hand, mostly adopts the mode of actuality by constantly giving a contemporary relevance to the figure of memory, initially based on a memory of a story that proceeds through black/white, Christian/heathen, city/country binaries. If anything, his cultural memory situates him at a point of emphasizing particularity in the assemblage of the black experience, unlike Abrahams's mode that stresses unity in that assemblage.

Suffice to conclude that these two types of positioning render each autobiography as belonging to either molar or molecular multiplicities; for that sense of unity in which Abrahams stakes a claim is largely about belonging to a unifiable multiplicity called the Black Atlantic, organizable by the principle of the double consciousness. Mphahlele articulates African humanism as a multiplicity that is not totalisable but amenable to change over periods of time and according to the contingencies of space. Having concluded thus, I hope at least to have offered a new reading of the two autobiographies by formally analysing cultural memory and, in the process, found congruent philosophical correlates of that cultural memory in Deleuzean thought, without necessarily inaugurating a binary between each memoric mode as expressed in the two novels. Each is bound in the tension between belonging and becoming. It is a question of degrees of orientation, of intensities of multiplicity, rather than the simple account - and count of repetition of figures of memory.

\section{References}

Abrahams, Peter. $\quad$ 1954. Tell Freedom. London: Faber. 2000. The Black Experience in the Twentieth Century: An Autobiography and Meditation. Bloomington: Indiana University Press.

Assmann, Jan. 1995. "Collective Memory and Cultural Identity", New German Critique 65 (Spring/Summer): 125-134.

Attwell, David. 1993. "Interview with Homi Bhabha", Current Writing 5(2): 100-113. 
Kgomotso Masemola

2001. "Fugitive Pieces: Es'kia Mphahlele and the African Diaspora”. Discussion paper, University of Natal, [reappears in Harlow, B and T Falola (eds) African Writers and their Readers (2002) New Jersey: Africa World Press.

Bhabha, Homi K. 1994. "The Postcolonial and the Postmodern". In: The Location of Culture. London \& New York: Routledge: 171197.

Boehmer, Elleke. 1995. Colonial and Postcolonial Literature. Oxford: OUP.

Brah, Avtar. 1996. Cartographies of the Diaspora: Contesting Identities. London: Routledge.

Bromley, Roger. 2000. Narratives for a New Belonging: Diasporic Cultural Fictions. Edinburgh: Edinburgh University Press.

Deleuze, Gilles and Claire Parnet. 1987. Dialogues. Trans. H Tomlinson and B Habberjam. New York: Columbia University Press.

Deleuze, Gilles. 1994. Difference and Repetition. Trans. Paul Patton. London: Athlone Press.

Fanon, Frantz. 1986. Black Skin, White Masks. London: Pluto Press.

Gates, Henry Louis Jr. 1989. $\quad$ Figures in Black: Words, Signs, and the "Racial" Self. Oxford and New York: Oxford University Press.

Gilroy, Paul. 1993. The Black Atlantic: Modernity and Double Consciousness. London: Verso.

Hall, Stuart. 1990. "Cultural Identity in the Diaspora”. In: Rutherford, J (ed) Identity: Community, Culture, Difference. London: Lawrence: 222-237.

1994. "Cultural Identity and Diaspora". In: Williams, P and L Chrisman (eds). Colonial Discourse and Postcolonial Theory. Hemel Hampstead: Harvester Wheatsheaf: 392-403.

Hughes, Langston and Annar Bontemps (eds). 1949. The Poetry of the Negro: 1746-1949. New York: Doubleday \& Co.

Mphahlele, Ezekiel. 1959. Down Second Avenue. London: Faber.

Ogungbesan, Kolawole.1979. The Writing of Peter Abrahams. London: Hodder \& Stoughton.

Olney, James. 1973. Tell Me Africa: An Approach to African Literature. Princeton: Princeton University Press.

Woeber, Catherine. 1995. "Error in the Religious Equation", English Academy Review 12, December: 58-69. 